\title{
The procedure and practice of witness testimony in English ecclesiastical courts, c.1193-1300
}

\author{
Sarah B. White
}

\begin{tabular}{|c|c|}
\hline Date of deposit & 19072019 \\
\hline Document version & Author's accepted manuscript \\
\hline Access rights & $\begin{array}{l}\text { Copyright (c) Ecclesiastical History Society } 2020 \text {. This work is } \\
\text { made available online in accordance with the publisher's policies. } \\
\text { This is the author created, accepted version manuscript following } \\
\text { peer review and may differ slightly from the final published } \\
\text { version. }\end{array}$ \\
\hline $\begin{array}{l}\text { Citation for } \\
\text { published version }\end{array}$ & $\begin{array}{l}\text { White, S. B. (2020). The procedure and practice of witness } \\
\text { testimony in English ecclesiastical courts, c.1193-1300. In The } \\
\text { Church and the Law (Vol. 56, pp. 114-130). (Studies in Church } \\
\text { History; Vol. 56). Cambridge University Press. }\end{array}$ \\
\hline $\begin{array}{l}\text { Link to published } \\
\text { version }\end{array}$ & https://doi.org/10.1017/stc.2019.7 \\
\hline
\end{tabular}

Full metadata for this item is available in St Andrews Research

Repository at: https://research-repository.st-andrews.ac.uk/

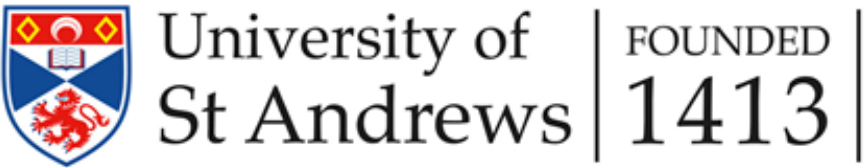


This essay explores three issues relating to proof by witnesses in the English ecclesiastical courts: the admission of witnesses who legally should have been barred from testifying; the use of public reputation as proof apart from ex officio inquest proceedings; and whether hearsay could constitute proof. ${ }^{1}$ When the church withdrew support for the ordeal at the Fourth Lateran council in 1215, the transition to an alternative system of proof was the work of Romano-canonical proceduralists. ${ }^{2}$ The procedure outlined in treatises, such as the Ordo of Tancred of Bologna from c. 1215 and the later Speculum iudiciale of William Durantis from c. 1270, provided a means for examining witnesses in a manner which would elicit the truth, as well as rules for rejecting witnesses and resolving conflicts. ${ }^{3}$ Although this procedure left some discretion to the judge, most procedural writing tended to limit the judge's discretion in the matter by providing rules by which he made decisions rather than guidance as to how he was to exercise his discretion. ${ }^{4}$

There were a number of forms of proof that could be used in the ecclesiastical courts, including confession, presumptions, written evidence, oaths of parties, inquests of sworn individuals, and witness testimony, with the last of these being by far the most common form of proof. ${ }^{5}$ This essay discusses the use of witnesses, using the case records of the metropolitan appeal court of Canterbury. This court was chosen in part due to the large number of extant records, as diocesan court records for the twelfth and thirteenth centuries only survive in small, scattered collections, mainly consisting of correspondence rather than formal case records. The extensive collection at Canterbury allows for a broad sampling of material, especially as these records contain not only the proceedings of the court of appeal, but often also the proceedings from the lower courts from which the appeal was made. ${ }^{6}$

\footnotetext{
${ }^{1}$ I am grateful to William Eves, John Hudson and Attilio Stella for their helpful comments on drafts of this essay. Any errors or omissions are my own.

${ }^{2}$ Charles Donahue Jr, 'Proof by Witnesses in the Church Courts of Medieval England: An Imperfect Reception of the Learned Law,' in On the Laws and Customs of England: Essays in Honor of Samuel E. Thorne, ed. by Morris S. Arnold and others (Chapel Hill, 1981), 129. For further discussion of the ordeal in canon law, see also Robert Bartlett, Trial by Fire and Water: The Medieval Judicial Ordeal (Oxford: Clarendon, 1986); Finbarr McAuley, 'Canon Law and the End of the Ordeal', Oxford Journal of Legal Studies 26 (2006), 473-513.

${ }^{3}$ Tancred, Ordo, in Pillii, Tancredo, Gratiae, Libri de Iudiciorum Ordine, ed. by F. Bergmann (Göttingen, 1842) [Hereafter Tancred, Ordo, along with the citation] and Guillaume Durand, Speculum Iuris: Cum Ioan. Andreae, Baldi, Reliquorum Que Clarisimorum, 2 vols (Lugduni: sumptibis Philippi Tinghi, 1578). [Hereafter referenced as Durantis, along with the citation].

${ }^{4}$ Donahue, 'Proof by Witnesses', 133.

${ }^{5}$ For more on each of these forms of proof, see Richard H. Helmholz, The Oxford History of the Laws of England, volume I, The Canon Law and Ecclesiastical Jurisdiction from 597 to the 1640s (Oxford, 2004), 327-41, and 604-617 for criminal procedure.

${ }^{6}$ All the cases mentioned are available in Select Cases from the Ecclesiastical Courts of the Province of Canterbury, c.1200-1301, ed. by Norma Adams and Charles Donahue Jr, Publications of the Selden Society, v. 95 (London, 1981),
} 
Strict rules existed in Romano-canonical procedure regarding witness testimony: witnesses had to be objective, as determined by their relationship to the parties, and they had to be eyewitnesses. Proof by two eyewitnesses was not always possible in practice, but cases still had to be resolved, presenting the court with the problematic option of accepting flawed testimony or no testimony at all. Out of necessity, witnesses who were not qualified to testify did so regardless, as did those who were not eyewitnesses. Further, many witnesses in the records testified to matters about which they had no personal knowledge, referring to things that were 'commonly known,' an acceptable form of proof in the inquisitorial criminal procedure of ex officio cases, but somewhat less so when establishing the substantive issues outside of ex officio proceedings. 'There are, however, both procedural and practical arguments which could allow for the use of public reputation in a trial outside ex officio inquests. Here a distinction must be made between fama and hearsay: fama testifies to the knowledge of the community, things which are publica et notoria, whereas hearsay testifies to things heard from a single person, ex relatione, ex relatu, or per relatem. ${ }^{8}$

Statistics for the forms of proof may be compiled from Select Cases, but caveat must be made regarding them. They are based on a selection of cases made for the Selden volume, which in turn was drawn from a selection made by the prior and chapter of Canterbury. Chosen as they were to demonstrate a range of cases, they cannot be seen as representative of the case records as a whole. That being said, they can still provide some insight into the types of evidence found in depositions. Of the fifty-two cases in sections A, C and D of Select Cases, there are 543 individual depositions. Of these, $87 \%$ refer to eyewitness testimony (either exclusively, or in conjunction with fama or hearsay), 36\% refer to fama (either exclusively, or in conjunction with eyewitness testimony or hearsay), and $8 \%$ refer to hearsay (either exclusively, or in conjunction with eyewitness testimony or fama). Do these different levels of appeal to varying types of evidence relate simply to practical issues,

hereafter Select Cases, followed by the case number, case name, and page number. The sample set of cases from Canterbury, being mainly appeals, is not representative of the full range of cases in the period, and the absence of straightforward cases in the record does not mean they did not occur. That being said, appeals were rarely made in clearcut cases, and the difficult or contentious issues which reached the metropolitan court are those in which procedure may have been tested more rigorously. It is also possible that this collection of cases was selected by the prior and chapter of Canterbury to demonstrate their exercise of vacancy jurisdiction, which had been previously challenged. See Select Cases, Introduction, 35-37.

${ }^{7} E_{\boldsymbol{X}}$ officio procedure was very similar to secular presentment procedure, to the extent that Richard Helmholz has suggested 'concrete connections between secular and canon law in the sphere of criminal procedure,' due to parallels in the three procedural stages of both systems: public fame, use of inquests, and purgation. However, there is one significant difference between the two: canonical inquests required the questioning of individuals, which differs from the practice of the self-informing secular jury. Richard H. Helmholz, 'The Early History of the Grand Jury and the Canon Law', University of Chicago Law Review 50 (1983), 613-627, at 616, 623, 625.

${ }^{8}$ See Select Cases, A2, 4; A3, 8-9; A4, 14; D11, 500-503; D16, 575, 585; D19, 650. 
or were other factors involved as well? To address this question, this essay will first outline academic witness procedure, specifically with regard to suitability of witnesses, followed by an examination of the use of this procedure in practice. It will then discuss the complexities surrounding the use of local opinion as proof outside of ex officio cases, both with regard to the technical use of fama and the more dubious use of hearsay.

\section{The Persons of Witnesses}

In ecclesiastical procedure, parties could produce any number of witnesses at each term designated for this production. Testimony was not given publicly in court; rather, witnesses were examined in private from a list of interrogatories, that is, questions drawn up by one side or the other on the basis of the articles or points to be proven. These depositions were written down and delivered to the judge for eventual publication to the parties. In practice, the total number of witnesses could vary. Tancred states in his Ordo that at least two witnesses were needed to make a full proof, but a few cases in the Canterbury material have well over twenty, and the canonical limit was forty. ${ }^{9}$ According to Tancred's Ordo, if a witness contradicted himself, the testimony should be rejected, and if the group of witnesses seemed to agree, their testimony should be followed. If the witnesses for one party disagreed amongst themselves, then the judge had to choose which of their statements fit the matter best and which were least suspicious. If the witnesses of the two parties disagreed, the judge was to reconcile their testimonies if possible, and if this were not possible, he should decide according to those which were more trustworthy, based on their social standing and relationship to the party: freeborn over freed, older over younger, a man of property over a pauper, the noble over the ignoble, a man over a woman, a friend of the defendant over his enemy. If all the witnesses were of the same dignity and status, then the judge was to decide by number. If they were the same in number as well, the judge was to absolve the defendant. ${ }^{10}$

The standard restrictions regarding witnesses can be found in Tancred's Ordo and the Canterbury material seems to follow these exceptions quite closely. ${ }^{11}$ Many types of people were

\footnotetext{
${ }^{9}$ Donahue, 'Proof by Witnesses', 130. In Select Cases, D14, Official of Lincoln c. John de Arden (1291-92) there are forty.

${ }^{10}$ Tancred, Ordo 3.6, De testibus; Donahue, 'Proof by Witnesses', 131. See also Charles Donahue Jr, 'Procedure in the Courts of the Ius Commune', in The History of Courts and Procedure in Medieval Canon Law, ed. by Wilfried Hartmann and Kenneth Pennington (Washington, DC, 2016), 83-94.

${ }^{11}$ Tancred, Ordo, 3.11, De testium reprobatione; see also Pseudo-Ulpian, De edendo, Bruce Brasington, Order in the Court: Medieval Procedural Treatises in Translation (Leiden: Brill, 2016), 153-55; and the Ordo Bambergensis in Brasington, Order in the Court, 238-49. It is interesting to note here that these exceptions also appear in Glanvill
} 
forbidden by law from testifying: the unfree, paupers or vagabonds, the excommunicate or those accused of crime, proctors or advocates in the principal case if the case in question was an appeal, servants or relatives of the producing party, or known enemies of the party against whom they were produced. Since exceptions were not raised against witnesses until after they had testified, no one was excluded from testifying, but doubt could be cast on their testimony after the fact. Rather than delay the examination until each witness was proved to be unexceptionable, it must often have been expedient to postpone exceptions until after testimony was given as all the exceptions could then be submitted at once. Postponing also gave the other party time to discover and consolidate further exceptions. This system also afforded an opportunity to ask for a delay, which one could argue was the most common reason for introducing anything additional to the case. In the same way, it is probable that exceptionable witnesses were introduced specifically to slow down the case and give the producing party more time to formulate their arguments, amass funds, or simply frustrate their opponent. $^{12}$

Once a witness had testified, the opposing party would not ask that the testimony be excluded; rather he would argue that no faith should be placed in the person of the witness, a phrase which suggests that the value of a testimony was left to the discretion of the judge following production. $^{13}$ Rather than the sentence depending solely on the number of unexceptionable witnesses produced by the parties, it appears that testimonies given by witnesses were evaluated in comparison with one another; the persons of the witnesses, internal consistency and details given in the testimony were all considered when deciding which party had the more convincing proof. ${ }^{14}$

As an example, in Master Robert de Pitchford c. Thomas de Neville (1267-72), a case which

indicating that these same restrictions may have been placed on jurors in the secular courts. The Treatise on the Laws and Customs of the Realm of England Commonly Called Glanvill, ed. by G. D. G. Hall and M. T. Clanchy, Oxford Medieval Texts (Oxford, 1993), 32.

${ }^{12}$ Donahue, 'Proof by Witnesses', 144.

${ }^{13}$ Ibid., 146.

${ }^{14}$ The most common questions regarded the witness' status, relationship to the parties and possible prejudice or corruption, along with the necessary questions about the case. See Select Cases, C11, Ascelina, prioress of Higham c. Amfelicia, subprioress and the nuns of Higham 'adhering to her' (1270), 163; C12, Philip, rector of Guestling c. the abbot and convent of Battle (1270-71), 192-193; C14, The prior and monks of Stogursey c.John de Winton, rector of Over Stowey (1271-72), 211; C18, Master Robert de Pitchford c. Thomas de Neville (1267-72), 270, 291; D11, Nicholas Lewyn, rector of Frankton c. Master Adam de Botingdon (1288-93), 498; D17, Robert Dyne c. Henry Dyne (12931294), 617, 626. These questions were highly specific and would often concern the weather, how the witness knew about the events, and the time of day at which something took place. When recording the depositions, the standard practice in the Canterbury cases was to record the first testimony in full, and details in the rest only when they differed from the first. Durantis objected to this practice, emphasising in the Speculum that all depositions were to be recorded in full (Durantis, Speculum, 1.4. [2], de teste, section 7.8). Donahue observes that the abbreviated system of recording depositions was approved in the statutes of the Court of Canterbury in 1342 (Select Cases, 50). 
concerned the question of who was the canonically instituted rector of the parish church at Houghton, Robert's counsel argues the following series of points against Thomas's witnesses:

Robert de Empinham gives false testimony when he says that Robert [de Pitchford] was not at the church of Houghton, because Robert [de Pitchford]'s witnesses have proved the contrary. Simon de Skeffington is a layman and cannot have knowledge of the letters of proxy. Geoffrey de Marefield is perjured because he said his co-witnesses were freemen, whereas three, Sampson, William son of Geoffrey, and Simon son of Robert, were serfs. Moreover, his testimony about the tithes was vacillating and contradictory and based on belief rather than knowledge. Walter, son of Henry, knows nothing about the letters of proxy. Roger de Billesdon does not testify consistently about the proxy. Sampson ad Ecclesiam does nothing to the point. William, son of Geoffrey, was under the command of [Roger Corbet's mother] who favoured Thomas. Simon son of Robert de Skeffington proves nothing about the proctors. John de Frisby used the words in possessione rather than possedit as claimed in the article of Thomas, nor does he say for what purpose the proctors were given. The same objection goes for Roger Halden, and he does not give the reason for his information about the possession and proxy, as required by the interrogatories. Nicholas de Halstead does not give the reason for his knowledge and is a serf. Lastly, the admission of these witnesses is not legally valid because Thomas renounced his right to produce witnesses on these matters. ${ }^{15}$

A number of these exceptions are against the persons of the witnesses: either they are serfs and therefore not able to testify, or they are prejudiced on behalf of Thomas, like William, son of Geoffrey, who was under the command of Thomas's patrons. Some are laymen and as a result, Robert's counsel argues, they could not have understood Thomas's letter of proxy correctly. Some do not prove what they were produced to prove, like Roger Halden, who did not provide the information required in the interrogatories and some, as was concisely said of Sampson ad Ecclesiam, did nothing to the point. What is more interesting, perhaps, is the exception against Geoffrey de Marefield, which states that the examiners found his testimony 'vacillating and contradictory.' An inconsistent or wavering testimony indicated that he may not have been be telling the truth, or that he was unsure of his story. However, Thomas later tried to argue that the case should be settled in his favour since he had a greater number of witnesses than Robert, indicating that at least at that point, Thomas's excepted witnesses had not been discounted out of hand. ${ }^{16}$

\section{Eyewitnesses and Fama}

\footnotetext{
${ }^{15}$ Select Cases, C18, Pitchford c. Neville, 308. Paraphrased translation by the author.

${ }^{16}$ Ibid., 327.
} 
In addition to the suitability of the persons of witnesses, Romano-canonical procedure required witnesses to be eyewitnesses of an event. The limitations on who could be a witness make sense in many ways: the ideal witness would have seen the events in question first-hand and have a reputation that was beyond reproach. In reality, however, these ideal witnesses would seldom be available. Perhaps someone had observed a disputed marriage first-hand, but she was the bride's sister and therefore could be prejudiced in some way. A man might be very trustworthy and have no connections to the party whatsoever, but only have heard of the marriage, and not seen the parties exchange their vows. For these reasons, the court may have accepted testimonies from exceptionable witnesses simply because there were no other options in some cases. In cases where the judge was presented with an array of suspect witnesses and varying testimonies, public reputation was essential for corroborating accounts. ${ }^{17}$

In interrogatories, witnesses were often asked to testify to anything to which they knew ' $s i$ visu, auditu, sciencia, credulitate aut fama. ${ }^{18}$ Often in the case of this last type of knowledge, these broader testimonies refer to whether or not someone was generally regarded to be the rector of the church in question or something similar, but they could also testify to the custom in the area (for example regarding mortuary payments). This was not just a quirk in the way that testimonies are given; in the interrogatories prepared for the examiners, they are often told to make close inquiry concerning the source of the witness's knowledge. ${ }^{19}$ The proof then depended on the uniformity of a group's testimony concerning public knowledge. In this way, witnesses could be treated more like a trial jury than like the eyewitnesses found in the Romano-canonical tradition, and the evidence in the English ecclesiastical material suggests that witnesses were indeed being used in this unconventional way.

Another unconventional use of witness testimony is worth noting here. In canon law, exceptions that were directly contrary to the initial claim could not be brought after the publication

\footnotetext{
${ }^{17}$ Richard Helmholz has noted that proof by notoriety, which certainly played a significant role in $e x$ officio proceedings, played a 'distinctly minor' role in instance cases. Although witnesses often stated that something was very well known, this was rarely relied on as full proof. Helmholz, The Oxford History, 328.

However, $40 \%$ of the depositions found in the sample set from Select Cases contain a combination of eyewitness account, testimony on the basis of fama, and reports of hearsay. Select Cases, C18, Pitchford c. Neville, is a good example of this, as is D16, Master Thomas de Sutton and Oliver Sutton, bishop of Lincoln c. Master Edward de St. John (1293-94), 567-611, a dispute over the prebend of Thame. For further work on this latter case, see Felicity G. Hill, Excommunication in Thirteenth-Century England: Community, Politics and Publicity (forthcoming).

${ }^{18}$ For an example, see Select Cases, C18, Pitchford c. Neville, 270-71. These categories can be found in a mnemonic in the gloss on the Liber extra, X.2.20.37 de testibus, Additio: 'Auditus, visus, persona, scienta, causa, / fama, locus, tempus, ac certam, credulitasque, / Dum testes recipit, judex haec cuncta notabit.'

${ }^{19}$ Select Cases, C18, Pitchford c. Neville, 268.
} 
of testimony. Perhaps to avoid this issue of timing, it appears that parties began to bring substantive exceptions by presenting them as exceptions against witnesses on the grounds that they had perjured themselves. To cite Pitchford c. Neville again, Thomas excepted that some of Robert de Pitchford's witness had perjured themselves when they said that his servant, also called Robert, was in possession of the church of Houghton, because on the days mentioned, Robert the servant was in Northampton and therefore could not have been present on the day stated.$^{20}$ While the exception was technically made against the witnesses and their supposed perjurious testimonies, the issue that is at stake was that Robert de Pitchford had no representative in possession of the church on the days he had said he did. An exception of absence would have been directly contradictory to the depositions on behalf of Robert de Pitchford stating that he had had a representative at the church, which had already been published, and therefore not permitted..$^{21}$ Although this exception did not mean that a new inquiry was made into Robert the servant's presence at the church, it may have resulted in the judge being slightly more sceptical of Robert de Pitchford's proofs. This manoeuvre was risky, as it could appear to be wilfully dilatory and the offending party could be liable to pay costs for the delay. It could also be that it was a last-ditch effort to shift the direction of the case. Regardless of the intent, this use of exception demonstrates that litigants and their counsel were very familiar with standard procedure, and that they were able to use it to their best advantage...

To return to the issue at hand, the use of witnesses almost as a secular jury could be attributed in part to the litigants themselves who, lacking witnesses in whom they were confident, sought to present the judge with witnesses who instead could testify to opinion in the community. Regardless of the content of the case, litigants may have been hard pressed to produce unexceptionable witnesses; those ideal witnesses who had been present at a marriage or institution might be ill, absent, or deceased when it came to the litigation. It seems that litigants were also, unsurprisingly, only concerned about the suitability of the other party's witnesses. Presenting as many witnesses as possible, then trying to discredit opposing witnesses until a conclusion was achieved through sheer numbers was a reasonable tactic to try. In cases like this, a version of events agreed upon by as many

\footnotetext{
${ }^{20}$ Ibid., 283-4.

${ }^{21}$ Ibid., 279.

${ }^{22}$ See also Select Cases, D5, Oliver de Brocton c. Adam Mulgars (1292-93), 395; D7,John St John, prior of Andover c. Executors of Edmund Paty (1293-94), 418; D9, Prior and convent of Kyme c. Lady Matilda de Croft (1292-93), 670; Select Cases, Introduction, 51-52; Elham c. Alice in Charles Donahue Jr, 'Roman Canon Law in the Medieval English Church: Stubbs vs. Maitland Re-Examined after 75 Years in the Light of Some Records from the Church Courts', Michigan Law Review 72 (1974), 647-716; and for further discussion Sarah B. White, Procedure and Legal Argument in the Thirteenth Century English Ecclesiastical Courts (forthcoming).
} 
people as possible, regardless of the source of their information, must have seemed like a reasonable substitute, especially keeping in mind the self-informing jury of the secular courts or the oath-helpers of compurgation procedure. In the secular courts, jurors were required to come from the locality of the case so that they could hear the case and judge the evidence presented on the basis of informed knowledge, even if they themselves had not been eyewitnesses of an event. ${ }^{23}$ Even in cases where eyewitness testimony was requested, parties seem to have been unwilling to abandon the notion that the witness was to testify concerning not only what they themselves had seen, but what the community believed the truth to be. ${ }^{24}$

The main concern of the courts, on the other hand, was the conclusion of cases. In cases which could be concluded realistically by the testimony of two unexceptionable eyewitnesses, such as a marriage case, the court might be more likely to insist on adherence to these rules. In other cases, especially a benefice case like Pitchford $c$. Neville, it might be more expedient to allow parties the opportunity to present groups of witnesses testifying to opinion of the community. Mike MacNair rightly notes the ecclesiastical courts' use of 'documents, witnesses, and procedure per notorium on the basis of personal knowledge of the ecclesiastical judge,' and the acceptance of local opinion as a form of proof. ${ }^{25}$ However, public knowledge as proof differed slightly from the canonical notion of fama in inquisitorial procedure, that is, ex officio procedure. Ex officio procedure was used primarily in cases of 'spiritual crimes,' such as adultery, when the court itself took on the responsibility of prosecuting a case initiated by public fame and determined with an inquest similar to a secular jury. ${ }^{26}$ Nevertheless, there is a crucial procedural difference here in that ex officio cases were meant to depend on fama: it was fama or notoriety that initiated the case in the first place, and fama that played the largest role in the inquiries. ${ }^{27}$ In contrast, substantive matters in non-office cases had to be proved by witnesses testifying about direct knowledge, not that of the community. ${ }^{28}$

That being said, judges may have turned to fama to fill in the gaps when testimonies were

\footnotetext{
${ }^{23}$ Mike MacNair, 'Vicinage and the Antecedents of the Jury', Law and History Review 17 (1999), 537-590, at 538.

${ }^{24}$ Donahue, 'Proof by Witnesses', 148.

${ }^{25}$ MacNair, 'Vicinage and the Antecedents of the Jury', 548.

${ }^{26}$ Donahue, 'Roman Canon Law', 618-19. The preference for witnesses in Romano-canonical procedure has often been contrasted with the secular juries to suggest fundamental differences between the two systems. See primarily Pollock \& Maitland, The History of English Law 137 (1898), 604 n.1. For a discussion of whether or not secular juries were truly self-informing, see Daniel Klerman, 'Was the Jury Ever Self-Informing?', Southern California Law Review 77/123 (2003), 123-150.

${ }^{27}$ The use of fama and issues of due process in criminal proceedings has been discussed at length by Richard M. Fraher, 'Conviction According to Conscience: The Medieval Jurists' Debate Concerning Judicial Discretion and the Law of Proof', Law and History Review 23 (1989), 23-88.

${ }^{28}$ Ibid., 36, n. 89.
} 
wanting. The gloss on the Liber extra states that fama alone could not constitute a full proof except in cases of impediments to marriage.$^{29}$ However, when fama was added to an eyewitness account, it had the effect of corroborating that account. This corroboration would make no difference in a case with two unexceptionable witnesses, but it could make a great deal of difference in their absence. ${ }^{30}$ In cases like this, a judge might use public reputation to determine which of two unreliable groups of witnesses was the more trustworthy. This was similar to two tactics often used by parties, the first of which was bringing as many witnesses as possible in the hope that unreliability would be outweighed by numbers, and the second of which was inviting witnesses of high social standing, whose reputation might balance out any deficiencies in their testimonies. In William Smith c. Alice Dolling (1271-72), William's claim was proved by ten witnesses whilst Alice's was only proved by four; as a result, William's claim was judged to be more valid..$^{31}$ Likewise, in The prior and monks of Stogursey c.John de Winton, rector of Over Stowey (1271-72), the proctor of John de Winton argued that all the opponent's witnesses had testified falsely, as shown by John's witnesses, who were greater not only in number, but also in dignity, reputation, and credibility. ${ }^{32}$ This approach did not always work, however. In Pitchford c. Neville, Thomas tried to argue that his witnesses outnumbered Robert's by sixteen to five and should therefore be preferred, 'since the laws are quicker to absolve than to condemn.' He added that even had their witnesses been of equal number and dignity, the judge should favour Thomas as the defendant. In civil trials, the burden of proof was upon the plaintiff, not the defendant, ${ }^{33}$ and Thomas seems to have been arguing here that Robert had not proved his point sufficiently. However, when the depositions are counted, Robert had twenty-two witnesses; significantly more than Thomas had claimed. Since Thomas had made exceptions to at least twelve of them earlier in the case, and presumably knew this, he may have been speaking at this point about the witnesses whose testimonies pertained to a particular article; however, if this was the case, he did not specify that it was so. ${ }^{34}$ In these cases, therefore, the opinion of a community could assist in overcoming deficiencies in evidence, allowing the judge to conclude a case in which the proof was imperfect. Local opinion concerning an event could also be treated as a presumption,

\footnotetext{
${ }^{20}$ Liber extra, X.2.24.32, gloss ex fama, 'Et ita patet, quod qualitercumque aliquid sit diuulgatum per famam, seu quasi notorium, non sufficit ad probationem ... sed cum aliis adminiculis sufficit ... sola fama sufficit ad matrimonium impediendum.'

${ }^{30}$ Fraher, 'Conviction According to Conscience', 36.

${ }^{31}$ Select Cases, C6, William Smith c. Alice Dolling (1271-72), 136.

${ }^{32}$ Select Cases, C14, The prior and monks of Stogursey c.John de Winton, rector of Over Stowey (1271-72), 221-22,

${ }^{33}$ Digest D. 22.3.2.

${ }^{34}$ Select Cases, C18, Pitchford c. Neville, 327,
} 
especially in marriage cases, where the knowledge of the community could be used to prove that a couple had been living together or had children. According to Ricardus Anglicus (writing in the $1190 \mathrm{~s})$ and to a number of decretals, this is the kind of case in which fama alone could be proof. ${ }^{35}$

\section{Fama and Hearsay}

Returning to Pitchford c. Neville, Robert and Thomas brought numerous exceptions against each other's witnesses; witnesses who had previously been excepted against nonetheless provide additional testimonies later in the case. ${ }^{36}$ Further, despite the large number of exceptions Thomas brought, Robert persisted in using the testimonies of these witnesses in his later arguments, indicating that despite these exceptions, his witnesses had not been entirely discounted. It is possible that all Thomas's claims were disproven, but as there is no record of this (or indeed of any replications, that is responses to his exceptions) it is as likely that these testimonies were still considered part of Robert's proof. Additionally, the examiners in the case were specifically requested to ask witnesses what the public report of the neighbourhood was. In Thomas's interrogatories, this is made even more clear: witnesses were to be asked how they knew about these matters, as was expected in inquiries about fama. If they said they knew who had had possession of the church by seeing, they were to be asked where, when, and whether the nature of the possession was natural or civil, mental or physical, and how long, and whether continuously or at intervals, the church had been possessed. If they knew anything by hearing, they were to be asked where, when, and from whom; if by knowledge, how; if by public report, from how many and how the report originated. ${ }^{38}$ From these interrogatories, is it clear that testimony that related to public reputation was acceptable and even required in this case in order to resolve the disagreement. At the close of Robert's first set of exceptions, the examiners added an extra marginal note commenting that Robert's witnesses had testified to the opposite of Thomas's witnesses, and that since Robert's witnesses all knew both the litigants and each other, and because more of them were from the local area, they to be were deemed

\footnotetext{
${ }^{25}$ Summa de Ordine ludiciario of Ricardus Anglicus, Ludwig Wahrmund, ed., Quellen zur Geschichte des R6mischkanonischen Prozesses (1905-1931; reprint, Aalen: Scientia Verlag, 1962), vol. 2, iii, pp. 1-114, at p. 62: 'Ratione cohabitationis, distantiae vel vicinitatis, ut supra de poen. di. I sed et continuo, qui dixerat et cet.'; p. 6: 'Ex communi et vulgari opinione, ut ff. ad Macedonianum, 1. si quis patrem...'; Liber extra, X.2.23.11 'Verum, quia in huiusmodi dubietate fama vicinia magis debet attendi... si fama loci habet, quod vir ipsam in lecto et in mensa sicut uxorem tenuerit, quum matrimonium sit maris et feminae coniunctio...'. See also MacNair, 'Vicinage and the Antecedents of the Jury', 577.

${ }^{36}$ See Robert Wenge and Roger Woodstock, Select Cases, C18, Pitchford c. Neville, 283-287, 329-330.

${ }^{37}$ Ibid., 268.

${ }^{38}$ Ibid., 269.
} 
more trustworthy. ${ }^{39}$ In a case like this, in which both parties produced large numbers of both witnesses and exceptions, it seems the request in the interrogatories for knowledge other than eyewitness knowledge was intended to help corroborate accounts and determine whether there was internal consistency amongst the two groups. The questions regarding public knowledge in this case also served to help prove who was generally thought to be the canonically instituted rector of the church of Houghton. Although some witnesses might not themselves have been present at the institution, they would have heard about the event from other members of the community, and being local residents, their report was taken into account.

Fama still had to be proved by witnesses, who were examined regarding the source of the reputation, and it could only be proved by those of good reputation who had reason to know about the debated question. ${ }^{40}$ Further, proving the existence of fama could be difficult, due to the problematic nature of hearsay. Romano-canonical procedure limited witnesses to testifying about things which they knew directly: therefore, a witness could not attest to fama because he had heard it from others, but rather had to testify that a great part of the populace knew something to be true. ${ }^{41}$ Yet even the use of hearsay might be acceptable proof in some cases. There were loopholes of sorts in procedure which allowed for proof memoria facti and ab auditu. In the Digest, there are two passages which suggest that the memory of things done, even when known through hearsay, could be used as proof. ${ }^{42}$ The Digest specifically says that a general recollection of seeing or hearing about an event is sufficient, even if details are lacking, since most people will not remember specifics such as date and time. Ricardus Anglicus, who was writing in the 1190s and whose work heavily influenced Tancred's Ordo, suggested that in cases of consanguinity, witnesses could testify de visu et auditu. ${ }^{43}$ Following the Fourth Lateran Council, the standards for witnesses were tightened and Tancred followed these restrictions. ${ }^{4}$ In particular, the author of the ordo 'Scientiam', claimed that the

\footnotetext{
${ }^{39}$ Ibid., 278.

${ }^{40}$ Fraher, 'Conviction According to Conscience', 34, n. 74. For a general discussion of fama in medieval Europe, see Thelma Fenster and Daniel Lord Smail, eds, Fama: The Politics of Talk and Reputation in Medieval Europe (Ithaca, 2003).

${ }^{41}$ Fraher, 'Conviction According to Conscience', 34.

${ }^{42}$ Digest D.22.3.28 '....sed cum omnium haec est opinio nec audisse nec vidisse, cum id opus fieret, neque ex eis audisse, qui vidissent aut audissent: et hoc infinite similiter susum versum accidet, cum memoria operis facti non exstaret,' and D.39.3.2.8 '....an memoria exstet facto opere, non diem et consulem ad liquidum exquirendum, sed sufficere, si quis sciat factum esse, hoc est, si factum esse non ambigatur: nec utique necesse esse superesse qui meminerint, verum etiam si qui audierint eos, qui memoria tenuerint.'

${ }^{43}$ Richard was here citing the Decretum C.35 q. 6 c. 5 : '.. quicquid inde scis aut audisti a tuis vicinis, a a tuis propinquis antiquioribus, tu per nullum ingenium ...'; C. 35 q. 6 c. 8 : '... sed potius, quia credant ita verum esse, et ita se a suis antecessoribus audivisse.'

${ }^{4}$ Liber extra, X.2.20.47, 'Ponit concilium duodecim, sine quibus ad probandum consanguinitatem in causa
} 
decision in the decretals meant that all testimony ab alio auditu was prohibited, denying that the Roman sources supported it at all. ${ }^{45}$ However, Durantis allowed for memoria facti to be applied in cases of prescriptive title, quite possibly because witnesses would not be available for a matter so far in the past. ${ }^{46}$ The Ordo Bambergensis (c. 1182), notes that two forms of hearsay are acceptable as proof: 'we knew it from our own ears or we learned that it was so from the report of others.' This is an argument which Bruce Brasington notes as unique in the ordines. ${ }^{47}$ It would appear from its use that the author of the treatise considered public reputation alone was a valid form of proof, but this affirmation is followed up with the caveat that hearsay is only acceptable 'in the aforementioned cases and especially those whose origins exceed our memory. ${ }^{18}$ Therefore, the opinion of a community could have varying force as proof depending on the context in which it was used.

\section{Conclusions}

Considering these variations on the law of proof, it seems reasonable to conclude that the rule requiring two unexceptionable eyewitnesses was not adhered to very strictly. ${ }^{49}$ In particular, differences between academic law and practice do not mean that the former was ignored, but rather that in some cases, when strict adherence to academic law was not possible, solutions had to be found. Although exceptions were frequently brought against witnesses, their testimonies were still considered in judging, and public reputation was often used to support questionable testimonies. Extant records of sentences, unfortunately, are rare, and those we have shed very little light on the decision-making process of the judges after the testimonies had been given. Usually, they only state that the judge had brought the sentence according to the law and with the advice of the iuris periti,

matrimoniali, non valet testimonium de auditu.' Tancred, Ordo, 3.9 De iuramento testium, $\$ 1$.

${ }^{45}$ 'Testimonium autem de relatione non valet ... quod testimonium de auditu non valet excepta causa matrimonii secundum iura antiqua, sed illum revocatum est per Lateranense concilium. Diceret quidam, quod valet testimonium de auditu, ut si de opere antiquo quaeretur ... Sed si diligenter inspiciantur duae praedictae leges, reperietur, quod ibi non requiritur testomonium de auditu, sed de facti visu.' Wahrmund, Quellen Vol. 2, I, 51.

${ }^{46}$ Durantis, Speculum, 2.2, De probationibus $\$ 1.20$ : 'Ultimo quaerit qualiter fiet probatio communic opinionis, vel etiam praescriptionis tanti temporis, cuius memoria non existit? Etc.'; MacNair, 'Vicinage and the Antecedents of the Jury', 573-574, n. 147-151.

${ }^{47}$ Brasington, Order in the Court, 242 n. 345.

${ }^{48}$ 'Sed notandum quia ex auditu factum testimonium dupliciter dicitur: aut quia ita esse aurium experientia didicimus et cognovimus, aut quia aliorum relatu ita fuisse didicimus. Primum improprie dicitur testimonium de auditu, proprie vero de visu de eo, quod, cum fiebat, videndo audiendo plene percipiebat... Sed proprie dicitur testimonium de auditu, nec est acceptabile, nisi in praedictis casibus et his maxime, quorum origo temporum nostrorum memoriam excedit.' Der Ordo Iudiciarius de Codex Bambergensis PIN, ed. by Johann Friedrich von Schulte (Vienna, 1872 ), 309.

${ }^{49}$ Indeed, of the forty-two cases from Select Cases for which we have depositions, twelve of them record either only eyewitness or none at all, and that number of cases increases once the exceptions concerning witnesses have been considered (see cases A8, A10, C12, C16, C17, D5, D7, D8, D11, D17, D19). 
not that he was swayed or convinced by the proofs of one party or the other, or that the proofs of one party had damaged their case. In general, it seems as though internal consistency, not the number of unexceptionable witnesses, was to be preferred when deciding the case. Further, testimonies did not have to be eyewitness accounts, as Romano-canonical tradition would prefer it, and the English church courts accepted and even sought out testimonies that related local opinion in case. In this way, witnesses could be representative not only of their individual knowledge of a case, but of the alleged wider knowledge of the community. This could have been due to litigants' reluctance to abandon older forms of proof dependant on local reputation, as MacNair suggests, or a resistance to abandoning jury-like proceedings, as argued by Donahue. It could also be that judges, finding themselves frequently presented with insufficient or unsuitable witnesses, had to find ways to make do with what was available. There was a possible fourth reason as well: the use of the community to enforce a sentence after the conclusion of the case. An unwelcome sentence based on the testimony of only two witnesses, eyewitness or not, may have been difficult to enforce, and the involvement of the wider community in the resolution of a dispute could ensure that the case stayed settled.

Lastly, the separation of the roles of judge and witness in canon law may have played some part. A judge was only permitted to decide a case based on the evidence presented and proved in court, not by any personal knowledge, and witnesses, on the other hand, were to speak only from personal knowledge. This was a false division in some ways, as every judge would have to use his own discretion when deciding a case (despite the clear rules for accepting testimonies) and witnesses inevitably engaged in judgement when giving their testimonies. This contradiction can be seen even more clearly in the use of fama, testified to by non-eyewitnesses and speaking to the judgement of a community in a case, which may explain the proceduralists' uncomfortable relationship with this and other forms of local opinion. Public reputation as proof could also have caused some further concern in relation to the role of the judge, in that it may have been possible for a community to present an agreed-upon narrative to the court in order to validate local, unofficial adjudication. ${ }^{50}$ Speculation aside, case records demonstrate a persistent use of fama and occasionally even hearsay as proof in practice despite the development of the law of witnesses.

\footnotetext{
${ }^{50}$ MacNair, 'Vicinage and the Antecedents of the Jury', 589.
} 